\title{
Smart Helmet First Person View (Set-fpv) sebagai Perangkat Teknologi Pembelajaran Tatap Muka Virtual Semi Realistik pada Kelas Praktikum Elektropneumatik Jarak Jauh
}

\section{Smart Helmet First Person View (Set-fpv) as a Semi-Realistic Virtual Face-to-face Learning Technology Device for Long Distance Electropneumatic Practical Course Online Meeting}

\author{
Aditya Kurniawan ${ }^{1 *}$, Kholilatul Wardani ${ }^{2}$, Ilham Penta ${ }^{3}$ \\ ${ }^{1,2}$ Politeknik Kota Malang \\ Raya Tlogowaru no 3 Malang, (0341) 745088 \\ ${ }^{3}$ Southeast Asian Ministers of Education Organization \\ Kompleks Universitas Terbuka Pondok Cabe Pamulang Tangerang Selatan, (021) 7422154 \\ aditya@poltekom.ac.id ${ }^{1 *}$,wardani@poltekom.ac.id ${ }^{2}$, penta@seamolec.org ${ }^{3}$
}

\begin{abstract}
Abstrak - Adanya pandemi Covid-19 membuat dibatasinya aktivitas pembelajaran dalam bentuk pertemuan fisik. Kondisi tersebut mempengaruhi pembelajaran pada sekolah vokasi, termasuk politeknik, yang aktivitas praktiknya memerlukan pertemuan tatap muka. Agar kegiatan praktik dapat tetap dilaksanakan dengan baik, perlu dikembangkan metode praktikum jarak jauh yang memanfaatkan teknologi. Penelitian ini mengembangkan alat yang memadukan teknologi Internet of Things dan kamera berbasis Internet Protocol yang disebut Smart Helmet First Person View (Set-fpv). Perangkat Set-fpv yang digunakan dalam penelitian ini terdiri dari sebuah helm yang dimodifikasi dengan IP cam nirkabel, dan headphone Bluetooth yang tersambung ke Smartphone atau komputer praktikum. Penelitian dilakukan selama satu semester di Politeknik Kota Malang, Program Studi Teknik Mekatronika. Responden penelitian sebanyak 29 mahasiswa konsentrasi Otomasi Industri, dan 24 mahasiswa Konsentrasi Alat Berat yang mengikuti mata kuliah Elektro Pneumatik. Sebelum dan sesudah mengikuti praktik seluruh responden diberikan soal pretest dan posttest secara daring, kemudian hasil test antara kelompok kontrol yang menggunakan perangkat lunak simulasi FluidSim dengan kelompok eksperimen yang menggunakan Setfpv diperbandingkan nilai reratanya. Penggunaan bandwidth tertinggi pada perangkat Set-fpv sebesar 102,43 Mbps untuk melakukan streaming selama satu semester dengan resolusi 1080p terhadap delapan perangkat. Validasi perangkat dilakukan oleh ahli teknologi dengan indikator tujuh poin. Berdasarkan penilaian ahli teknologi nilai rerata penerimaan produk sebesar 88,5 persen yang tergolong baik, sedangkan hasil penilaian ahli materi dan ahli media sebesar 82,6 persen dengan penerimaan tergolong baik. Hasil penelitian menunjukan terjadi kenaikan nilai posttest dari pretest yaitu dengan peningakatan
\end{abstract}

TELKA, Vol.7, No.2, November 2021, pp. 108 119

ISSN (e): 2540-9123 
sebesar 9,59\% dengan nilai rerata sebesar 8,1 terhadap kelompok eksperimen, sedangkan pada kelompok kontrol sebesar 7,9.

Kata Kunci: Smart helmet first person view, IoT, IP Cam, praktikum jarakjauh, face-to-face, semi-realistic.

\begin{abstract}
The Covid-19 pandemic has restricted learning activities in the form of physical meetings. These conditions affect learning experience in vocational schools, including polytechnics. In order for the practical course to be carried out properly, it is necessary to develop a remote practical course method that utilizes technology. This research develops a tool that combines Internet of Things technology and Internet Protocol-based camera called Set-fpv (Smart Helmet First Person View). The Set-fpv device used in this study consisted of a modified helmet with a wireless IP cam, and Bluetooth headphones connected to a Smartphone or a computer. The research was conducted for one semester at the Politeknik Kota Malang, Mechatronic Engineering Program. The research respondents were 29 students of Industrial Automation concentration, and 24 students of Heavy Equipment Concentration who took the Electrical Pneumatics course. Before and after participating in the practical course, all respondents were given online pretest and posttest questions, the test results between the control group using the FluidSim simulation software and the experimental group using Set-fpv were compared with the mean values. The highest bandwidth usage on Set-fpv devices is 102.43 Mbps to stream for one semester with 1080p resolution on eight devices. Device validation is carried out by experts based on seven-point indicators. The results shows that (1) the validation results from tech experts, materials experts, and media experts with seven indicator points, reached $88.5 \%$ of validity by tech experts meaning a good acceptance conclusions and $82.6 \%$ by material and media experts meaning a good acceptance conclusions. (2) The highest total internet bandwidth usage (while using 1080p streaming) and 8 IoT smart switch devices is 102.43 Mbyte for 1 semester, and (3) Grades that are taken from a homogeneous student groups shows an increased in their practical performances. The results showed an increase of $9.59 \%$ with the the pretest value of 8.1 to the experimental group, while in the control group it was 7.9.
\end{abstract}

Keywords: Smart helmet first person view, IoT, IP Cam, online practical course, tatap muka, semi realistic.

\title{
1. Pendahuluan
}

Keadaan Indonesia saat ini sedang mengalami kondisi tidak baik disebabkan oleh virus berasal dari Wuhan, China yang dinamakan dengan Covid-19. Referensi [1], [2] [3] [4] [5] [6] dan [7] menyatakan bahwa virus ini penularannya sangat cepat dan dapat menyebabkan kematian. Virus ini menyerang infeksi saluran pernapasan seperti batuk dan pilek namun sifatnya lebih mematikan.

Berdasarkan [8] menyatakan bahwa selama pandemi maka pelaksanaan pembelajaran di rumah tempat tinggal masing-masing melalui metode pembelajaran jarak jauh dan atau secara virtual/ daring, dan pendidik yang melaksanakan tugas di rumah tetap melakukan tugas pembelajaran kepada mahasiswa. Meskipun peraturan ini bersifat regional Kota Malang saja, namun maklumat semacam ini sudah menjadi keumuman dan menjadi peraturan untuk hampir di setiap daerah yang terkena dampak pandemic Covid-19. Oleh karena itu, pembelajaran tatap muka masih menjadi opini yang mungkin akan banyak berubah dalam beberapa tahun kedepan.

Dalam hal penyelenggaraan Pendidikan vokasi di tingkat Pendidikan tinggi, praktikum daring selama ini masih dilaksanakan melalui penyampaian materi praktikum yang bersifat tutorial dan demonstrasi dalam bentuk video. Pendidik menyiapkan materi pengantar dalam praktikum mandiri kemudian peserta didik merekam hasil praktikum, dan atau tugas daring dan praktikum diberikan melalui program simulasi.

Berdasarkan [9] keterbatasan media akan menyebabkan kurangnya interaksi yang realistik antara peserta praktikum dan instruktur dalam proses praktik yang seharusnya. Media pertemuan daring seperti google meet, zoom, atau lainya hanya terbatas pada interaksi tatap muka (video) dan suara dari instruktur secara sinkron yang masih jauh dari standar interaksi yang dibutuhkan pada saat pelaksanaan praktikum jarak jauh yang dalam penelitian ini diambil contoh praktikum 
Elektro Pneumatik. Beberapa penelitian perangkat smart helmet yaitu [10], [11], [12] telah dimanfaatkan untuk aplikasi deteksi dan diagnosis. Sedangkan penelitian lainya [13] dan [14] menambahkan teknologi IoT dan penggunaan zigbee sebagai hardware node menunjukan pengembangan smart helmet ini dapat digunakan untuk kebutuhan peningkatan interaksi pembelajaran selama pandemi.

Untuk memenuhi kebutuhan interaksi tersebut dikembangkan sebuah rancangan alat bantu Set-fpv (Smart Helmet First Person View) yang akan dipasangkan pada peserta praktikum untuk memudahkan instruktur untuk mengendalikan jalanya praktikum dan memberikan suasana "realistic meeting experience" dalam tatap muka daring tersebut.

Tujuan penelitian yang akan dicapai adalah 1) mengembangkan prototype alat dukung pembelajaran berupa smart device Set-fpv yang dapat menambah interaksi belajar pada pembelajaran jarak jauh berbasis praktikum 2) tersusunnya artikel ilmiah yang siap diterbitkan pada Jurnal Online tentang efektifitas penggunaan peralatan yang dikembangkan.

Manfaat penelitian yang akan dicapai adalah 1) memberikan sumbangsih temuan berupa prototipe alat bantu dalam praktikum jarak jauh yang dapat menambah pengalaman tatap muka proses belajar menjadi semi realistis 2) menyebarkan ide ide baru dalam hal memecahkan masalah pendidikan dalam era pandemi Covid-19.

\section{Metode Penelitian}

Model pengembangan yang digunakan yaitu model Sugiyono [15] dengan Langkah 1) pemetaan potensi dan masalah, 2) mengumpulkan Informasi, digunakan sebagai bahan perencanaan produk 3) desain produk, 4) validasi 5) uji coba produk dalam bentuk prototype 6) eksperimen dengan kelompok kontrol dan 7) uji coba pemakaian. Bagan alur berpikir penelitian ini dapat dilihat pada Gambar 1 dengan Langkah akhir membandingkan indikator A dan B.
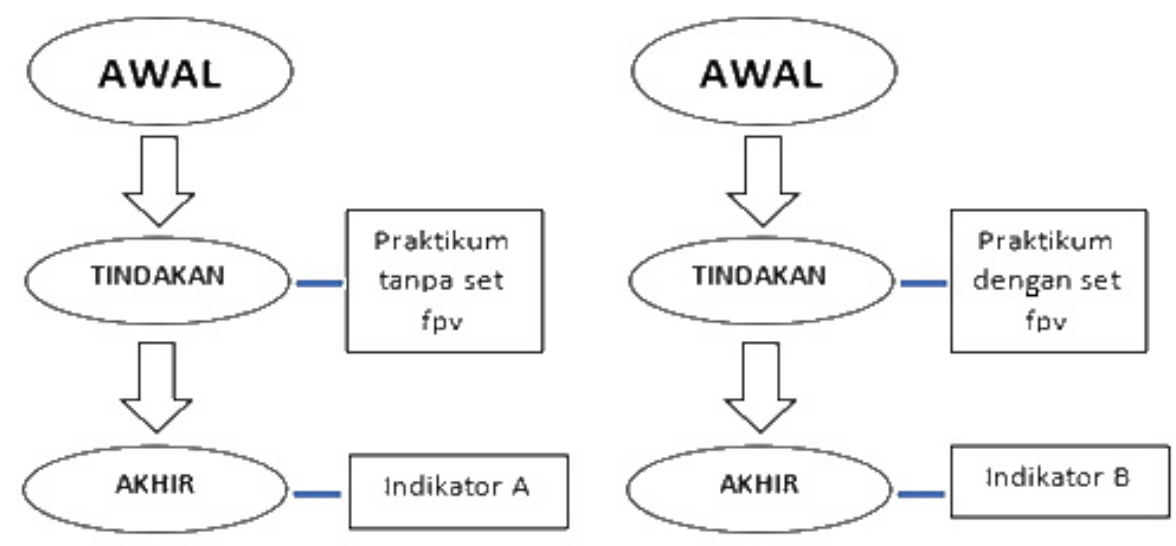

Gambar 1. Alur berpikir penelitian.

Validasi produk akan dilakukan oleh ahli media, ahli teknologi, dan ahli materi ditunjukan pada Tabel 1. Validasi dilakukan secara daring dengan mengamati proses pelaksanaan praktikum online. Dalam melakukan validasi, nilai dari para ahli akan dikelompokan dalam instrumen validasi yang ditampilkan dalam Tabel 2.

\begin{tabular}{|c|c|c|c|}
\hline \multirow{2}{*}{ Bidang Keahlian } & \multicolumn{2}{|c|}{ Pendidikan } & \multirow[t]{2}{*}{ Keterangan Posisi } \\
\hline & $\mathrm{S} 1 \quad \mathrm{~S} 2$ & $\mathrm{~S} 3$ & \\
\hline Ahli IoT & $\sqrt{ }$ & & Dosen Teknik Mekatronika \\
\hline Ahli Pneumatik & $\sqrt{ }$ & & Ketua Prodi Teknik Mekatronika \\
\hline Ahli Aplikasi Android & $\sqrt{ }$ & & Ketua Prodi Teknik Informatika \\
\hline Ahli Media & $\sqrt{ }$ & & Ketua Laboratorium Bahasa \\
\hline
\end{tabular}

ISSN (e): 2540-9123

ISSN (p): 2502-1982 
Tabel 2. Instrumen validasi.

\begin{tabular}{llll}
\hline Instrumen & Variabel & Indikator & Validator \\
\cline { 2 - 4 } & Kualitas isi & a) Kesesuaian komponen & Ahli \\
Angket & & b) Kesesuaian desain & Teknologi \\
dalam & & c) Kesesuaian program & \\
bentuk & Kualitas produk & d) Kesesuaian dengan sarana dan prasarana & \\
numerical & & a) Estetika & Ahli Materi \\
rating scale & & b) Kesesuaian fungsi & \\
& Impact & e) User friendly & Mahasiswa \\
& & a) Memudahkan praktikum online & \\
\hline
\end{tabular}

Sedangkan mekanisme traffic monitoring untuk perangkat IoT switch yang dibuat berdasarkan [4,5] dapat dilihat pada Gambar 2 dan Gambar 3.

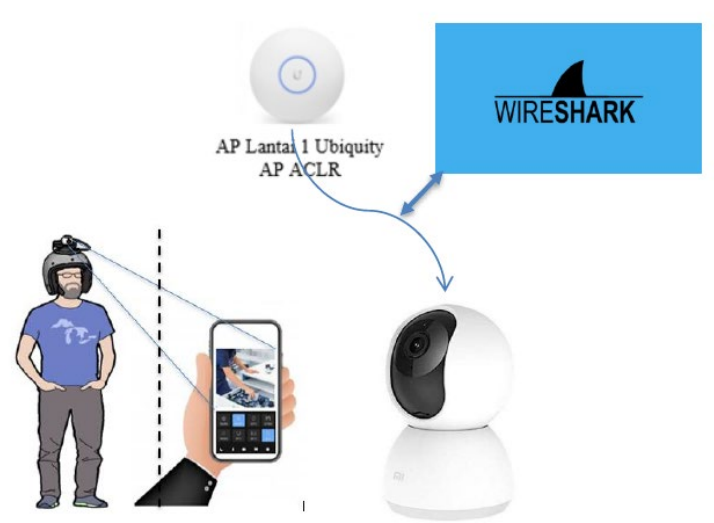

Gambar 2. Tapping jaringan IP cam Set-fpv.

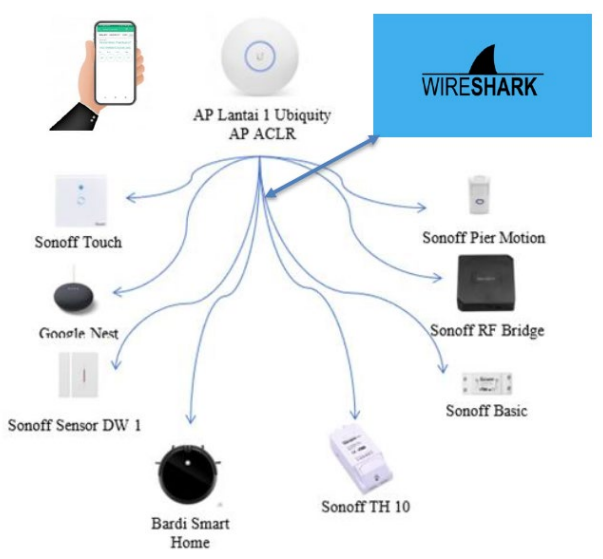

Gambar 3. Tapping jaringan IoT.

Selanjutnya diambil nilai pre test untuk kelompok mahasiswa eksperimen, dan kelompok mahasiswa kontrol. Metode pengumpulan data yang akan digunakan adalah dengan metode tes objektif menjawab pertanyaan ujian melalui e-learning setelah melaksanakan praktikum. Post test dilakukan dengan cara melakukan observasi terhadap hasil kerja praktikum juga dilakukan dengan memberikan tugas rangkaian elektropneumatik indirect AND berdasarkan [16] yang dapat dilihat pada Gambar 4 dan Gambar 5. Setelah itu, hasil pre test dan post test akan dibandingkan nilai rata rata nya.

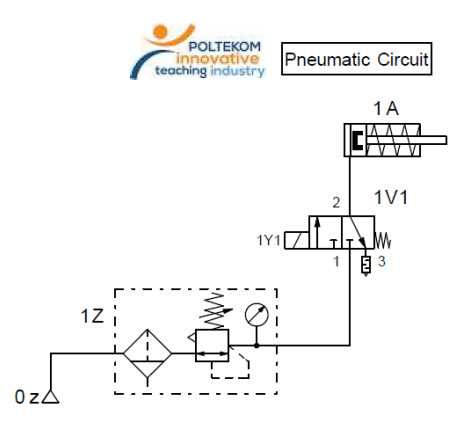

Gambar 4. Rangkaian pneumatik single acting cylinder.

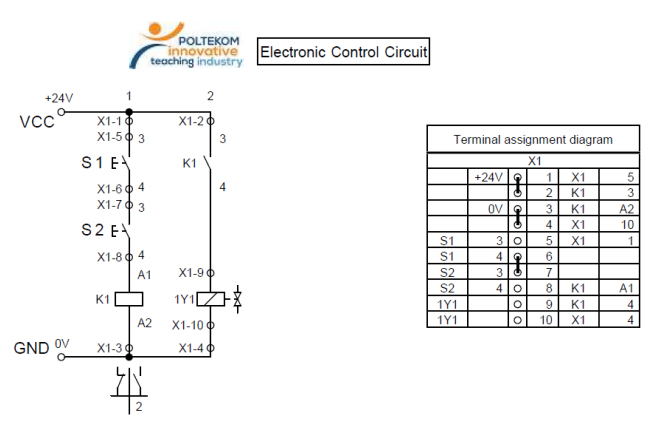

Gambar 5. Rangkaian kendali indirect AND.

\subsection{Perangkat Set-fpv}

Model pengembangan alat Set-fpv yang akan digunakan dalam penelitian ini terdiri dari sebuah helm yang dimodifikasi dengan IP cam yang terhubung secara nirkabel serta sebuah headphone bluetooth yang tersambung kepada HP atau komputer yang digunakan mahasiswa saat 
melakukan praktikum elektropneumatik. Desain Set-fpv dapat dilihat pada Gambar 6 dan Gambar 7.

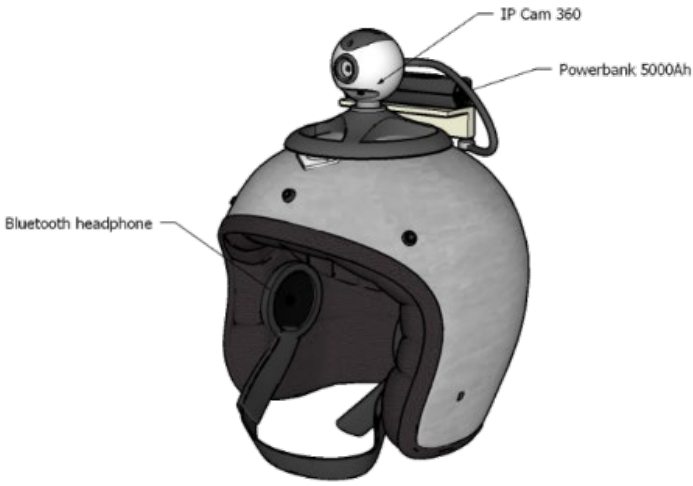

Gambar 6. Desain Set-fpv yang digunakan.

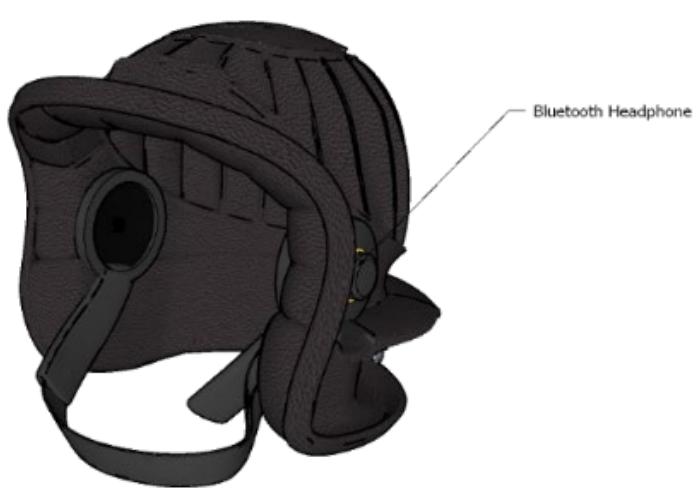

Gambar 7. Desain bluetooth speaker Set-fpv.

\subsection{Mekanisme praktikum jarak jauh dengan perangkat Set-fpv}

Pengumpulan data dilakukan secara daring dengan setting perangkat pada sisi mahasiswa adalah 1) komputer atau laptop yang memiliki koneksi bluetooth 2) perangkat mobile yang terinstal zoom atau google meet 3) perangkat Set-fpvdan 4) Trainer set elektropneumatik TP101. Mekanisme dan perangkar tersebut dapat dilihat pada Gambar 8.

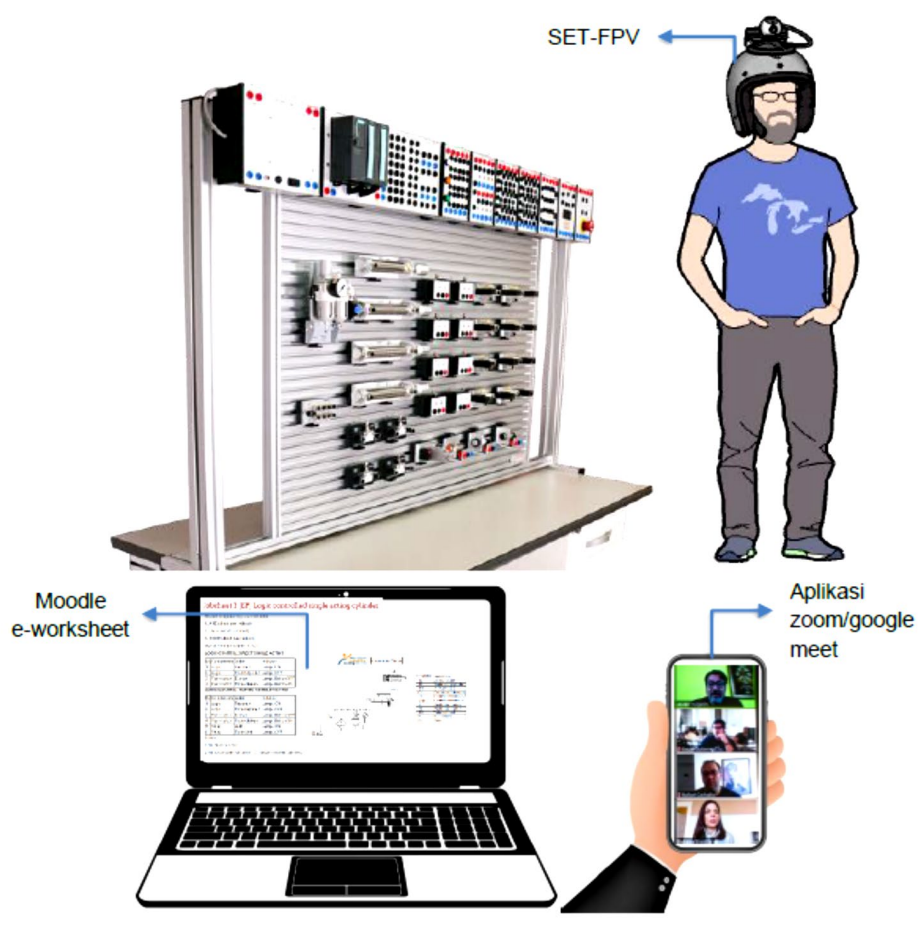

Gambar 8. Perangkat pada sisi mahasiswa.

Sedangkan pada sisi dosen adalah 1). komputer atau laptop yang memiliki koneksi bluetooth, 2). perangkat mobile yang terinstal aplikasi Set-fpv yang dikembangkan berdasarkan [4,5], 3). perangkat Set-fpv dan 4) Aplikasi IP cam Set-fpv. Mekanisme dan perangkar tersebut dapat dilihat pada Gambar 9. 


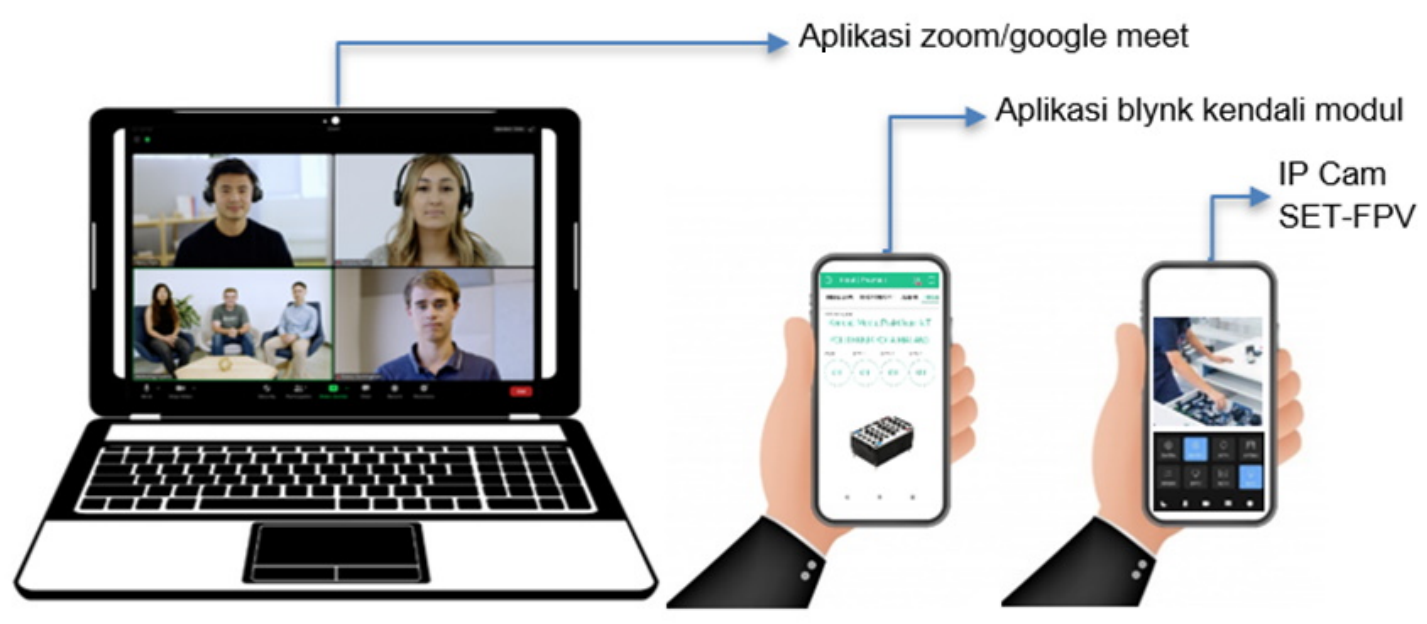

Gambar 9. Perangkat pada sisi dosen.

\section{Hasil dan Pembahasan}

Hasil pada penelitian ini adalah perangkat Set-fpv dan IoT smart switch untuk mata kuliah elektropneumatik dengan standar kompetensi elektropneumatik dasar rangkaian digital direct dan indirect. Set-fpv memiliki halaman 1). kendali lampu, 2). kendali kompresor, 3). kendali modul, 4). kendali AC, dan 5). Set-fpv view. Untuk lebih jelasnya dapat dilihat pada sesi praktik online pada Gambar 10.

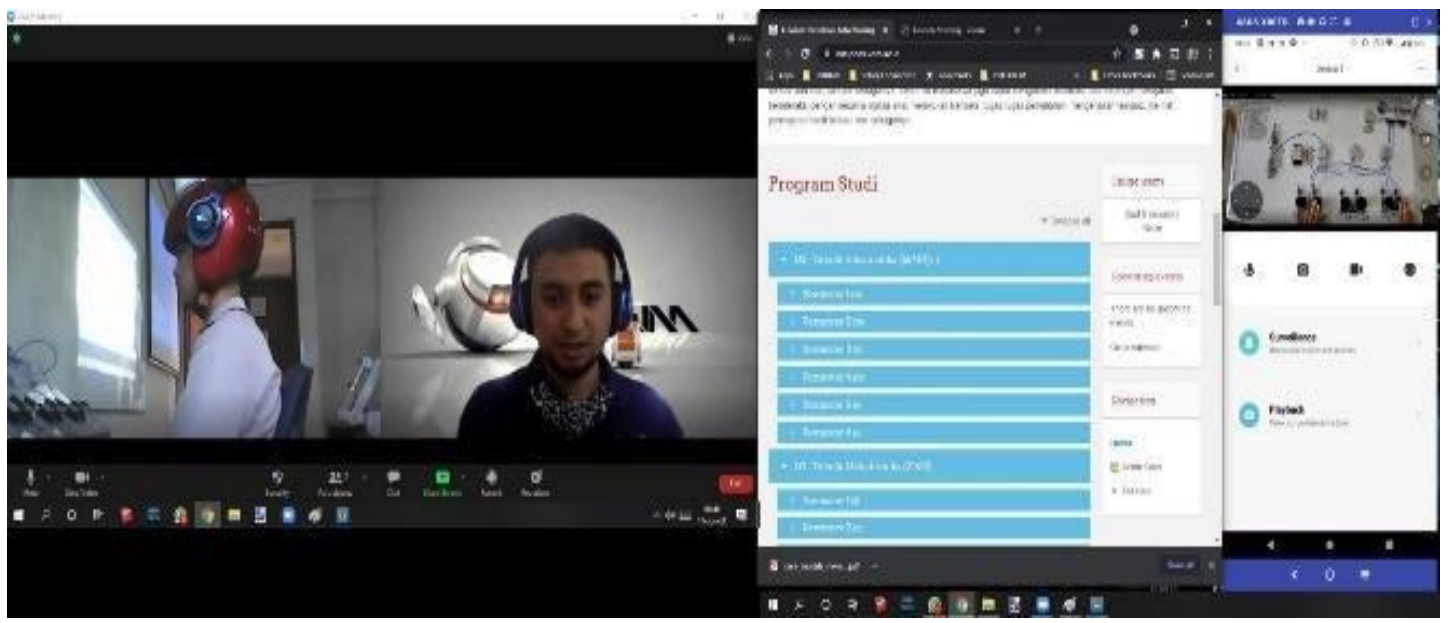

Gambar 10. Sesi praktikum online dengan perangkat Set-fpv.

\subsection{Interface Aplikasi}

Interface pada aplikasi berbasis android versi 9 yang dikembangkan dalam penelitian ini dibuat dengan prinsip ramah pengguna (user friendly), simple, dan dapat digunakan tanpa instruksi penggunaan yang khusus. Pada halaman pertama terdapat empat widget yaitu 1) widget text 2) widget text yang berisikan tulisan notifikasi instruksi penggunaan bertuliskan "tekan tombol untuk mengaktifkan" 3) image widget yang menampilkan gambar statis dari lampu yang terdapat pada laboratorium pneumatic dan 4) widget pill rounded button yang diatur dengan mode switch digunakan untuk menghidupkan dan mematikan lampu yang terdapat pada laboratorium pneumatik. Tangkapan layar halaman ini terdapat pada Gambar 11 dan 12. 


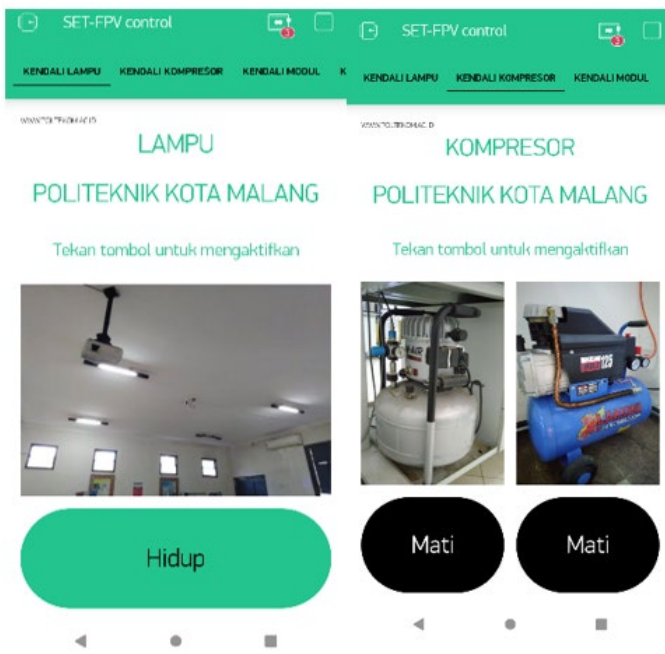

Gambar 11. Tangkapan layar aplikasi IoT 1.

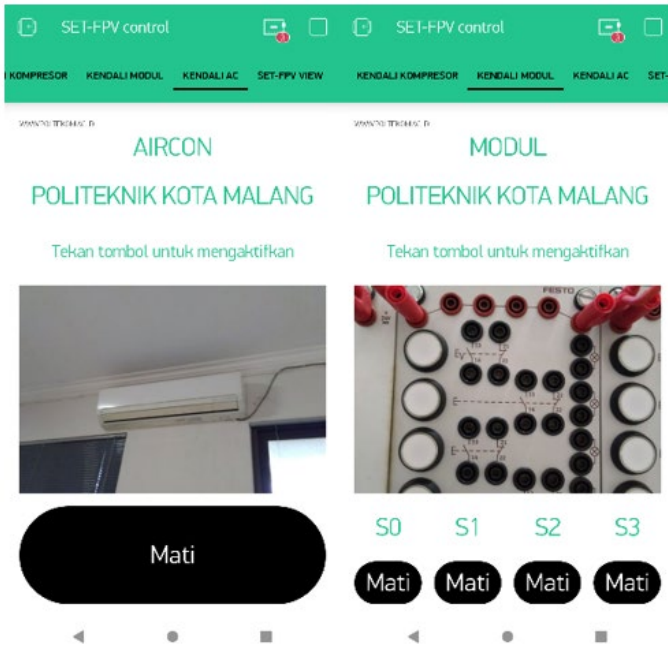

Gambar 12. Tangkapan layar aplikasi IoT 2.

\subsection{Hasil validasi perangkat Set-fpv}

Tahap validasi merupakan kegiatan mengukur ketepatan/kesahihan setiap bagian perangkat. Validasi dibedakan menjadi dua, yaitu 1) validasi teknologi dan 2) validasi materi. Instrumen validasi dapat dilihat pada Tabel 2 dan list nama validator dapat dilihat pada Tabel 1 . Hasil validasi dapat dilihat pada Tabel 3.

Tabel 3. Hasil validasi ahli teknologi.

\begin{tabular}{|c|c|c|c|c|c|}
\hline \multirow[b]{2}{*}{$\mathrm{NO}$} & \multirow[b]{2}{*}{ INDIKATOR } & \multirow[b]{2}{*}{$\begin{array}{c}\text { BUTIR } \\
\text { INDIKATOR }\end{array}$} & \multicolumn{2}{|c|}{ NILAI } & \multirow[b]{2}{*}{ PERSENTASE } \\
\hline & & & $\begin{array}{c}\text { Validator I } \\
\text { Rizki Priya } \\
\text { Pratama, } \\
\text { S.ST.,M.T.,M.Sc }\end{array}$ & $\begin{array}{c}\text { Validator II } \\
\text { Dita Lupita } \\
\text { Sari, } \\
\text { S.ST.,M.T. }\end{array}$ & \\
\hline 1 & Kesesuaian komponen & 2 & 5 & 4 & $90 \%$ \\
\hline 2 & Kesesuaian desain & $1,3,4$ & 4.3 & 3.6 & $79 \%$ \\
\hline 3 & Kesesuaian program & 1,3 & 4.5 & 4 & $85 \%$ \\
\hline \multirow[t]{2}{*}{4} & $\begin{array}{l}\text { Kesesuaian dengan } \\
\text { sarana dan prasarana }\end{array}$ & 7,8 & 5 & 5 & $100 \%$ \\
\hline & & Jumlah skor & 18.8 & 16.6 & $88.5 \%$ \\
\hline
\end{tabular}

Sedangkan hasil validasi materi dapat dilihat pada Tabel 4.

Tabel 4. Hasil validasi ahli materi dan media.

\begin{tabular}{|c|c|c|c|c|c|}
\hline \multirow[b]{2}{*}{$\mathrm{NO}$} & \multirow[b]{2}{*}{ INDIKATOR } & \multirow[b]{2}{*}{$\begin{array}{c}\text { BUTIR } \\
\text { INDIKATOR }\end{array}$} & \multicolumn{2}{|c|}{ NILAI } & \multirow[b]{2}{*}{ PERSENTASE } \\
\hline & & & $\begin{array}{c}\text { Validator I } \\
\text { Helmy Mukti } \\
\text { Himawan, } \\
\text { S.ST.,M.T. }\end{array}$ & $\begin{array}{l}\text { Validator II } \\
\text { Choirun } \\
\text { Niswatin } \\
\text { S.Pd.,M.A. }\end{array}$ & \\
\hline 1 & Estetika & $1,4,5$ & 4 & 3.3 & $73 \%$ \\
\hline 2 & Kesesuaian fungsi & $2,6,7,8$ & 4 & 4.5 & $85 \%$ \\
\hline \multirow[t]{2}{*}{3} & User friendly & 3 & 5 & 4 & $90 \%$ \\
\hline & & Jumlah skor & 13 & 11.8 & $82.6 \%$ \\
\hline
\end{tabular}

Dari Tabel 3 dan Tabel 4 dapat diketahui bahwa hasil validasi dari ahli teknologi, ahli materi, dan ahli media mendapatkan nilai tertinggi pada dua poin dari tujuh poin yaitu pada poin indikator kesesuaian komponen dan sifat user friendly dari perangkat dengan nilai $90 \%$. Sedangkan nilai

ISSN (e): 2540-9123

ISSN (p): 2502-1982 
rendah didapatkan pada poin indikator estetika dan kesesuaian desain aplikasi yaitu dengan nilai $73 \%$ dan $79 \%$.

\subsection{Hasil validasi perangkat Set-fpv}

Kelompok mahasiswa diberikan pretes berupa pertanyaan yang berkaitan dengan materi sebelum melakukan praktikum dengan Set-fpv untuk mendapatkan pengetahuan awal yang homogen. Bentuk tes tersebut adalah e-test yang dapat diakses dalam elearning. Daftar nama mahasiswa, pembagian kelompok dan hasil dari pre test dapat dilihat pada Tabel 5.

Tabel 5. Nilai pre tes dan pembagian kelompok.

\begin{tabular}{cllc}
\hline No & \multicolumn{1}{c}{ Nama } & \multicolumn{1}{c}{ Waktu Pengerjaan } & Nilai \\
\hline 1 & Mahasiswa 1 & 33 min 59 detik & 9,13 \\
2 & Mahasiswa 2 & 45 min & 9,20 \\
3 & Mahasiswa 3 & 42 min 53 detik & 8,43 \\
4 & Mahasiswa 4 & 24 min 20 detik & 8,70 \\
5 & Mahasiswa 5 & 43 min 44 detik & 8,90 \\
6 & Mahasiswa 6 & 35 min 21 detik & 9,20 \\
7 & Mahasiswa 7 & 28 min 53 detik & 9,10 \\
8 & Mahasiswa 8 & 25 min 6 detik & 8,85 \\
9 & Mahasiswa 9 & 34 min 36 detik & 9,30 \\
10 & Mahasiswa 10 & 45 min 1 detik & 8,94 \\
\hline
\end{tabular}

Nilai mahasiswa setelah melakukan tes direkam dan di analisis berdasarkan nilai yang didapatkan saat praktikum. Kelompok A akan mendapatkan sesi praktikum simulasi dan kelompok B akan mendapatkan sesi praktikum menggunakan Set-fpv. Pembagian kelompok A dan B didasarkan pada sebaran nilai pre test dan diasumsikan kedua kelompok memiliki kemampuan awal yang homogen. Nilai pre tes dari sepuluh mahasiswa sampel dapat dilihat pada Tabel 5. Dari tabel tersebut dapat disimpulkan rata rata nilai pretest adalah 9.0 dengan nilai tertinggi dan terendah adalah 9.3 dan 8.43 . nilai homogenitas dari pre test ini dapat dihitung dengan (1) membagi standar deviasi dengan rata rata nilai

$$
\text { Index Similarity }=\left(1-\frac{\sqrt{\sum_{i=1}^{n}|x-\underline{x}|^{2}}}{\frac{\sum_{i=1}^{n} X_{i}}{n}}\right) x 100 \%
$$

dengan $\mathrm{x}$ adalah nilai yang didapatkan dalam pre test dan $\mathrm{i}$ adalah banyaknya data nilai.

Untuk nilai pre test didapatkan index similarity sebesar 97\% dengan kesimpulan homogen. Setelah mendapatkan nilai kesamaan (similarity index) dari nilai tersebut, maka mahasiswa dibagi menjadi kelompok A dan kelompok B secara urutan dengan pembagian sebagaimana ditunjukan oleh Tabel 5. Secara observasi dan capaian praktikum didapatkan nilai praktikum kelompok A yang mendapatkan sesi praktikum simulasi ditunjukan oleh Tabel 6, sedangkan Nilai praktikum kelompok B yang mendapatkan sesi praktikum dengan Set- FPV ditunjukan oleh Tabel 7. Sampel rekaman video sesi praktikum dengan Set-fpv dapat dilihat pada link berikut https://youtu.be/81 tO-IfmafA dan https://youtu.be/PnXtCOBL 2g.

Tabel 6. Nilai praktikum online kelompok A.

\begin{tabular}{cccc}
\hline No & Nama & $\begin{array}{c}\text { Nilai } \\
\text { dengan } \\
\text { Set-fpv }\end{array}$ & $\begin{array}{c}\text { Nilai } \\
\text { tanpa } \\
\text { Set-fpv }\end{array}$ \\
\hline 1 & Mahasiswa 1 & 8.3 & 8.5 \\
2 & Mahasiswa 2 & 8.2 & 7.0 \\
3 & Mahasiswa 3 & 8.1 & 4.0 \\
4 & Mahasiswa 4 & 7.6 & 8.5 \\
5 & Mahasiswa 5 & 7.1 & 9.0 \\
\hline & Nilai rata rata & 7.9 & 7.3 \\
\hline
\end{tabular}

Tabel 7. Nilai praktikum online kelompok B.

\begin{tabular}{cccc}
\hline No & Nama & $\begin{array}{c}\text { Nilai } \\
\text { dengan } \\
\text { Set-fpv }\end{array}$ & $\begin{array}{c}\text { Nilai } \\
\text { tanpa } \\
\text { Set-fpv }\end{array}$ \\
\hline 1 & Mahasiswa 6 & 9.5 & 6.8 \\
2 & Mahasiswa 7 & 8.0 & 7.6 \\
3 & Mahasiswa 8 & 7.5 & 7.1 \\
4 & Mahasiswa 9 & 8.0 & 7.1 \\
5 & Mahasiswa 10 & 7.5 & 7.8 \\
\hline & Nilai rata rata & 8.1 & 7.3 \\
\hline
\end{tabular}




\subsection{Konsumsi bandwidth IoT switch}

Total jumlah IoT smart switch yang digunakan dalam penelitian ini adalah sebagai berikut 1) IoT smart switch lampu lab 2) IoT smart switch kompresor merk lakoni 3) IoT smart switch kompresor merek Festo 4) IoT smart switch air conditioner 5) IoT smart switch modul input S0 6) IoT smart switch modul input S1 7) IoT smart switch modul input S2 dan (8) IoT smart switch modul input S3. List perangkat yang digunakan ada pada Tabel 8 sedangkan skematik dapat dilihat pada Gambar 13.

Tabel 8. List identitas perangkat IoT smart switch.

\begin{tabular}{ccccl}
\hline No & $\begin{array}{c}\text { Tipe } \\
\text { Koneksi }\end{array}$ & Device Name & MAC Address & \multicolumn{1}{c}{ Fungsi } \\
\hline 1 & $2.4 \mathrm{G}$ & ESP_ECDE98 & DC-4F-22-C6-9C-B0 & Air Conditioner \\
2 & $2.4 \mathrm{G}$ & ESP_CE6EC1 & $60-01-94-C E-6 E-C 1$ & Lampu Lab \\
3 & $2.4 \mathrm{G}$ & ESP_8CB846 & $60-01-94-8 C-B 8-46$ & Kompresor merk Lakoni \\
4 & $2.4 \mathrm{G}$ & ESP_C6D60C & DC-4F-22-C6-D6-0C & Kompresor merk Festo \\
5 & $2.4 \mathrm{G}$ & ESP_CEBF16 & $60-01-94-C E-B F-16$ & Input Modul S0 \\
6 & $2.4 \mathrm{G}$ & ESP_BF8E0E & $60-01-94-B F-8 E-0 E$ & Input Modul S1 \\
7 & $2.4 \mathrm{G}$ & ESP_323D90 & 80-7D-3A-32-3D-90 & Input Modul S2 \\
8 & $2.4 \mathrm{G}$ & ESP 372CC6 & DC-4F-22-37-2C-C6 & Input Modul S3 \\
\hline
\end{tabular}

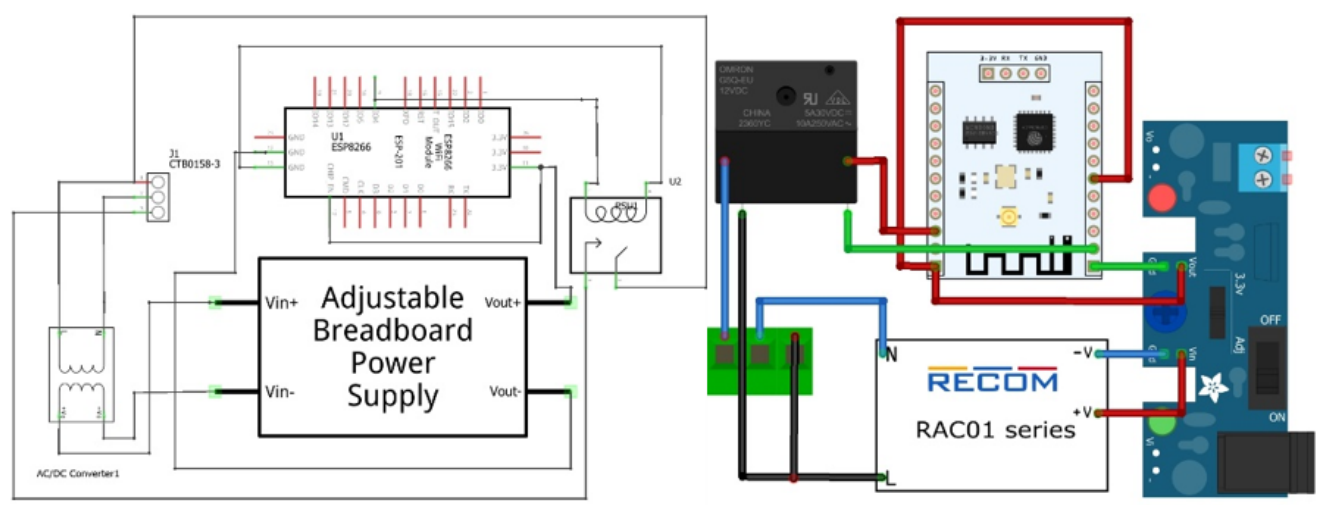

Gambar 13. Skematik diagram IoT switch.

Konsumsi bandwidth yang dimonitor selama 10 menit dengan sampel perangkat ESP_ECDE98 | DC-4F-22-C6-9C-B0 pada saat perangkat standby dapat ditunjukan pada Gambar 14. Traffic monitor menunjukan downlink rate adalah 2.1 byte/s dan uplink rate adalah 3.1 byte/s. sehingga konsumsi bandwidth selama 1 bulan diperkirakan 13.47 Mbyte untuk 1 perangkat.

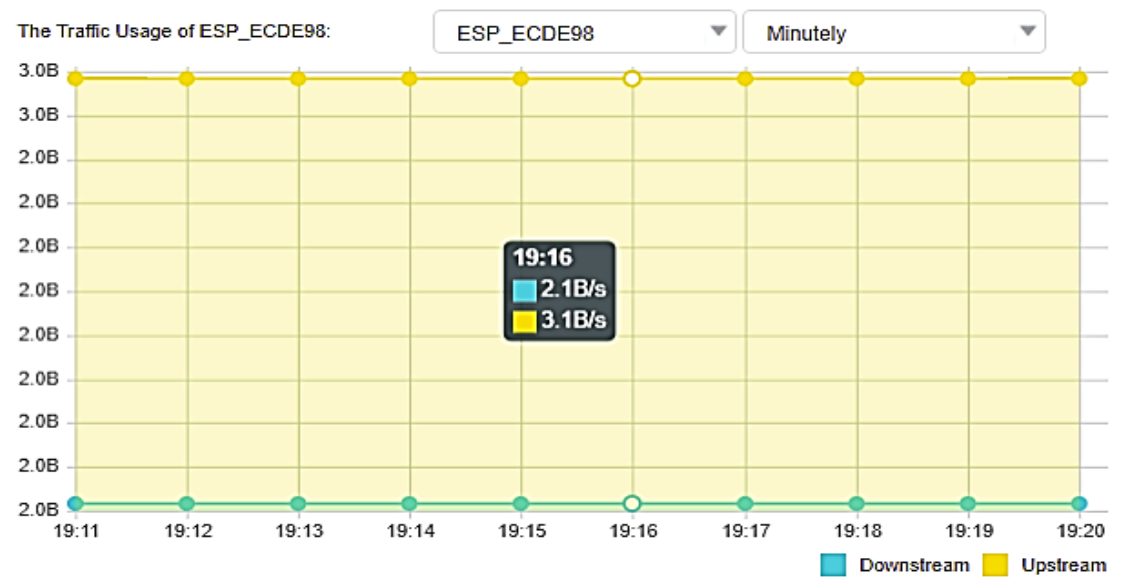

Gambar 14. Traffic monitor ESP_ECDE98 | DC-4F-22-C6-9C-B0. 


\subsection{Konsumsi bandwidth IP cam}

IP cam yang digunakan dalam penelitian ini adalah merek MiHome 360 dengan spesifikasi tertera sebagai berikut 1) nama produk Mi Home Security Camera $360^{\circ} 1080 \mathrm{p} 2$ ) model produk MJSXJ02CM 3) dimensi produk $78 \times 78 \times 118 \mathrm{~mm} 4$ ) daya input 5V 1A 6) sudut kamera $110^{\circ} 7$ ) resolusi maksimal 1080p 8) panjang fokus $3.9 \mathrm{~mm}$ 9) suhu pengoperasian $10^{\circ} \mathrm{C}-50^{\circ} \mathrm{C} 10$ ) konektivitas Wi-Fi IEEE $802.11 \mathrm{~b} / \mathrm{g} / \mathrm{n} 2.4 \mathrm{GHz} 11$ ) perangkat yang didukung adalah Android 4.4 atau IOS 9.0 dan 12) ID CMIIT2018DP2227. Identitas perangkat dapat dilihat pada Tabel 9.

Tabel 9. Identitas perangkat IP Cam Set-fpv.

\begin{tabular}{ccccc}
\hline No & $\begin{array}{c}\text { Tipe } \\
\text { Koneksi }\end{array}$ & Device Name & MAC Address & Fungsi \\
\hline 1 & $2.4 \mathrm{G}$ & chuangmi_camera_ipc009 & 44-23-7C-3E-01-AC & IP Cam FPV \\
\hline
\end{tabular}

Downlink dan uplink real time yang dimonitor selama 10 menit dalam kondisi standby dapat dilihat pada Gambar 15, sedangkan pada kondisi online dengan streaming 360p dapat dilihat pada Gambar 16, dan online dengan streaming 1080p dapat dilihat pada Gambar 17.

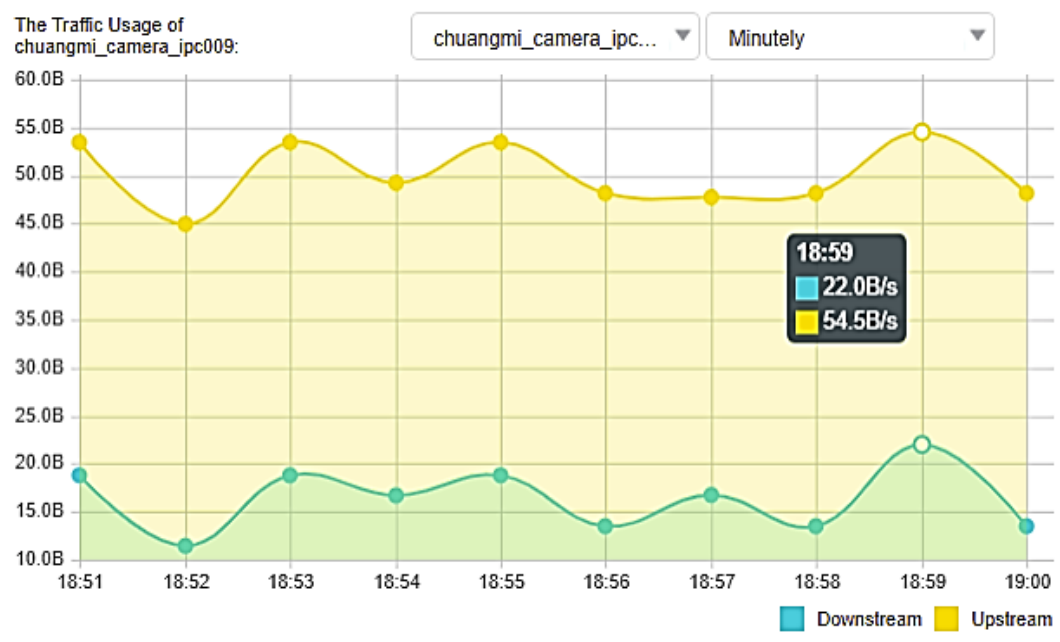

Gambar 15. Traffic monitor chuangmi_camera_ipc009|44-23-7C-3E-01-AC standby.

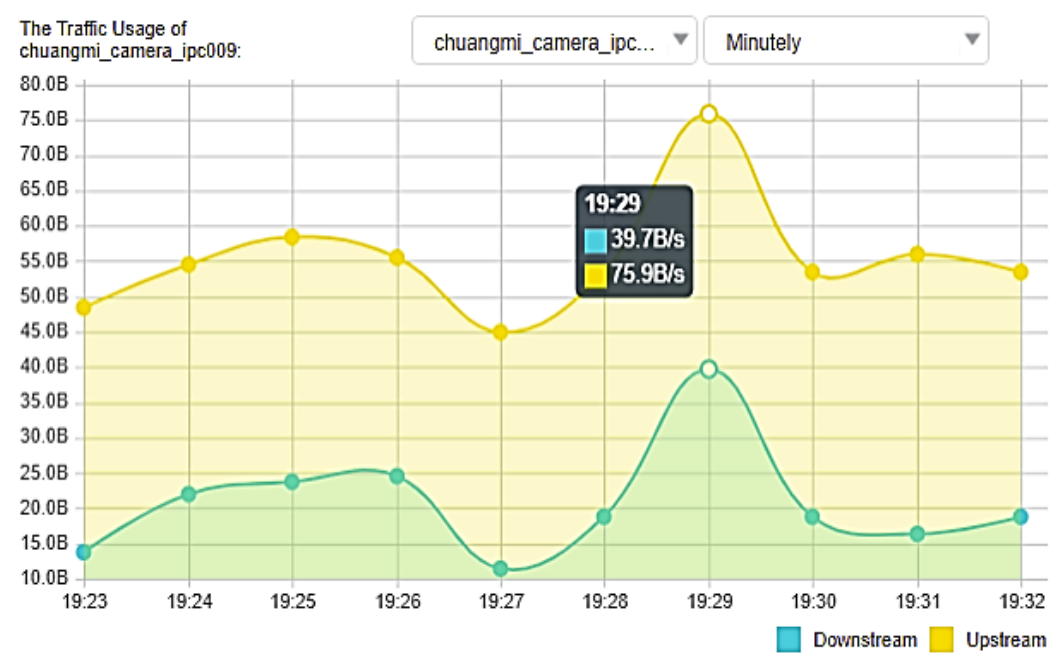

Gambar 16. Traffic monitor chuangmi_camera_ipc009|44-23-7C-3E-01-AC streaming 360p. 


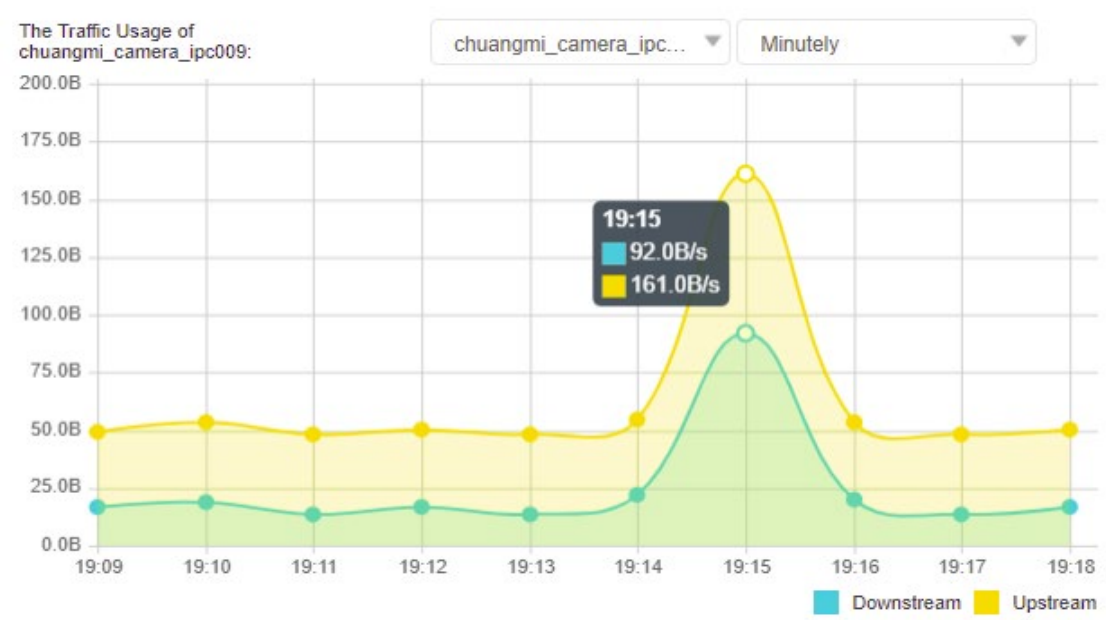

Gambar 17. Chuangmi_camera_ipc009|44-23-7C-3E-01-AC streaming 1080p.

Konsumsi bandwidth yang dimonitor selama 10 menit pada perangkat dengan device name chuangmi_camera_ipc009|44-23-7C-3E-01-AC pada saat perangkat standby ditunjukan dengan traffic monitor pada downlink rate tertinggi yaitu 22.0 byte/s dan uplink rate tertinggi 54.5 byte/s selama 10 menit, Rata rata downlink adalah 50.35 byte/s dan uplink adalah 16.5 byte/s. Pada saat perangkat melakukan streaming dengan resolusi 360p traffic uplink mencapai 75.9 byte/s dan downlink mencapai 39.7 byte/s. Sedangkan pada saat perangkat melakukan streaming dengan resolusi tertinggi yaitu 1080p, traffic uplink mencapai 161 byte/s dan downlink mencapai 92.0 byte/s. Sehingga diperkirakan untuk konsumsi bandwidth selama 1 jam adalah 416.16 kbyte untuk streaming 360p dan 910.80 kbyte untuk streaming 1080p.

\section{Kesimpulan}

Hasil pengembangan, validasi produk, dan uji coba prototype Set-fpv (smart helmet first person view) telah menunjukan beberapa hal yang cukup penting yaitu (1) hasil validasi dari ahli teknologi, ahli materi, dan ahli media dengan tujuh poin indikator yaitu $88.5 \%$ oleh ahli teknologi dengan kesimpulan penerimaan baik dan $82.6 \%$ oleh ahli materi dan media dengan kesimpulan penerimaan baik. (2) berdasarkan jam penggunaan praktikum mata kuliah elektronika pneumatik dengan komposisi 80\% praktikum dalam 16 pertemuan / semester (53.3 jam) maka penggunaan bandwidth internet yang terpakai untuk penggunaan bandwidth tertinggi (streaming 1080p) dan 8 perangkat IoT smart switch selalu standby adalah 102.43 Mbyte selama 1 semester, dan (3) Praktikum online dengan Set-fpv menunjukan nilai rata rata 8.1 dan 7.9 dibandingkan dengan kelompok kontrol yang menggunakan simulasi yaitu dengan nilai 7.3 untuk keduanya. Hal ini menunjukan kenaikan nilai rata rata praktikum mahasiswa sebesar $9.59 \%$ pada mahasiswa yang menggunakan perangkat Set-fpv pada sesi praktikum secara jarak jauh (online).

\section{Referensi}

[1] "Coronavirus disease (COVID19)," who, [Online]. Available: https://www.who.int/emergencies/diseases/novel-coronavirus-2019. [Diakses 9 Maret 2021].

[2] J. Chan, S. Yuan, K. Kok, K. To, H. Chu dan J. Yang, "A familial cluster of pneumonia associated with the 2019 novel coronavirus indicating person-to-person transmission: a study of a family cluster," Lancet, vol. 295, pp. 14-23, 2020.

[3] I. Ghinai, T. McPherson, J. Hunter, H. Kirking, D. Christiansen dan K. Joshi, "First known person-to-person transmission of severe acute respiratory syndrome coronavirus 2 (SARSCoV-2) in the USA," Lancet, vol. 395, pp. 1137-1144, 2020.

[4] C. Huang, Y. Wang, X. Li, L. Ren, J. Zhao dan ,. Hu, "Clinical features of patients infected with 2019 novel coronavirus in Wuhan," Lancet, vol. 395, pp. 497-506, 2020. 
[5] J. Liu, X. Liao, S. Qian, J. Yuan, Wang.F dan Y. Liu, "Community Transmission of Severe Acute Respiratory Syndrome Coronavirus 2," Emerg Infect Dis, vol. 26, no. 3, p. 1320, 2020.

[6] R. Pung, C. Chiew, B. Young, S. Chin, M. Chen dan H. Clapham, "Investigation of three clusters of COVID-19 in Singapore: implications for surveillance and response measures," Lancet, vol. 395, pp. 1039-1046, 2020.

[7] L. Luo, D. Liu, X. Liao, W. X, Q. Jing dan J. Zheng, "Modes of contact and risk of transmission in COVID-19 among close contacts," MedRxiv, 2020.

[8] "Peraturan Walikota Malang no 30 Tahun 2020," Hukumonline, [Online]. Available: https://covid19.hukumonline.com/wpcontent/uploads/2020/09/peraturan_wali_kota_malang_nomor_30_tahun_2020.pdf. [Diakses 9 Maret 2021].

[9] Dubey, Pushkar dan P. Deepak, "Distance learning in higher education during pandemic: challenges and opportunities," Int. J. Ind. Psychol, vol. 8, no. 2, pp. 43-46, 2020.

[10] T. e. a. Eldemerdash, "IoT Based Smart Helmet for Mining Industry Application," International Journal Advance Science Technology, vol. 29, pp. 373-387, 2020.

[11] J. Mingi, "Development and application of the smart helmet for disaster and safety," dalam International Conference on Information and Communication Technology Convergence (ICTC), Jeju Island, 2018.

[12] P. a. D. S. Roja, "Iot based smart helmet for air quality used for the mining industry," Int. J. Res. Sci. Eng. Technol, vol. 4, pp. 514-521, 2018.

[13] Sanjay dan S. Bhagat, "Smart helmet using zigbee," Int. J. Innov. Res. Technol, vol. 6, pp. 144-148, 2019.

[14] M. Mohammed, "Novel COVID-19 detection and diagnosis system using IOT based smart helmet," International Journal of Psychosocial Rehabilitation, vol. 7, no. 24, pp. 22962303, 2020.

[15] Sugiyono, Metode Penelitian Kuantitatif Kualitatif dan R\&D, Bandung: Alfabeta, 2011.

[16] "Electropneumatics Workbook," Festo, 2016. [Online]. Available: https://www.festodidactic.com/ov3/media/customers/1100/541090_v2.1_leseprobe_en.pdf. [Diakses 9 Mei 2021].

[17] P. Waher, P. Seneviratne, B. Russell dan D. Duren, IoT, Packt Publishing, 2016.

[18] "Introduction: Blynk Documentation," Blynk, 2021. [Online]. Available: https://docs.blynk.io/en/. [Diakses 9 Mei 2021]. 